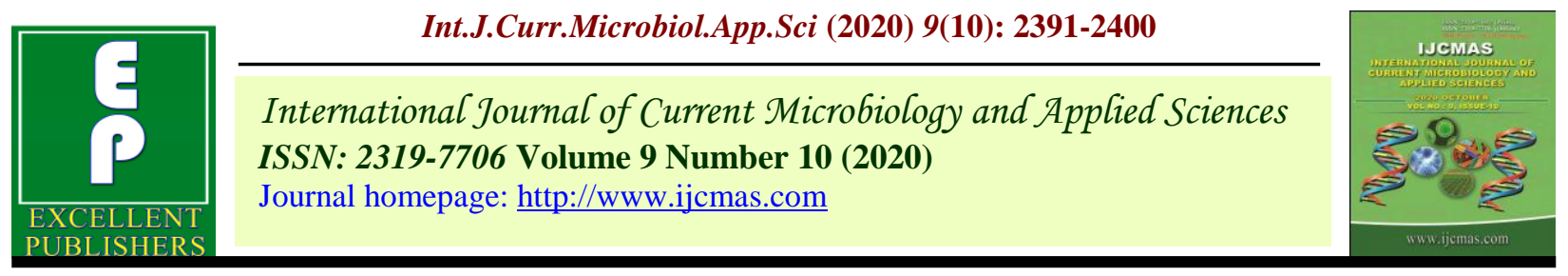

Original Research Article

https://doi.org/10.20546/ijcmas.2020.910.286

\title{
A Study of Anthropometric Profile of Diabetic and Non Diabetic Men
}

\author{
Karmjeet Kaur*, Harpreet Kaur, Kiran Bains and Jaswinder K. Brar \\ Department of Food and Nutrition, Punjab Agricultural University, Ludhiana-141004 India \\ *Corresponding author
}

\begin{tabular}{l} 
K e y w o r d s \\
$\begin{array}{l}\text { Type } 2 \text { diabetes, } \\
\text { Waist } \\
\text { circumference, Hip } \\
\text { circumference, } \\
\text { Body mass index }\end{array}$ \\
Article Info \\
$\begin{array}{l}\text { Accepted: } \\
17 \text { September } 2020 \\
\text { Available Online: } \\
10 \text { October } 2020\end{array}$ \\
\hline
\end{tabular}

A B S T R A C T

A total random sample size of 387 subjects was selected in the age group of $\geq 20$ years representing rural and urban area of Ludhiana district. The anthropometric measurements were taken of all the subjects to determine if it can be a risk factors of type 2 diabetes. The anthropometric profile of subjects revealed that the mean body weight of rural and urban diabetic men was $(78.85 \mathrm{~kg}, 75.58 \mathrm{~kg}$ respectively) significantly higher $(\mathrm{p} \leq 0.01)$ as compared to rural and urban non diabetic men $(72.14 \mathrm{~kg}$ and $70.97 \mathrm{~kg}$, respectively). Similarly, the waist and hip circumference of diabetic men was significantly higher $(\mathrm{p} \leq 0.01)$ as compared to non diabetic men. Derived anthropometric measurements of diabetic and non diabetic subjects showed that the average BMI of rural and urban diabetic men was significantly $(\mathrm{p} \leq 0.01)$ higher $\left(26.82\right.$ and $\left.26.71 \mathrm{~kg} / \mathrm{m}^{2}\right)$ as compared to rural and urban non diabetic men $\left(24.64\right.$ and $\left.24.91 \mathrm{~kg} / \mathrm{m}^{2}\right)$.

\section{Introduction}

Diabetes is a fast growing disease that will potentially lead to an epidemic in India (Joshi and Parikh, 2007 and Kumar, 2013). The causes of diabetes in India is increasing due to the factors combined with environmental effects such as obesity is associated with the sedentary lifestyle, urbanization, and increased standard of living. The prevalence of diabetes in the rural area is one-quarter that of the urban area for India and other Indian sub-continent countries such as Bangladesh, Bhutan, Nepal, and Sri Lanka (Wild et al., 2004 and Anjana et al., 2011). Primary results from a community-based study conducted by the ICMR (Indian Council of Medical research) showed that lower proportion of north Indian population is affected by the disease (Chandigarh with 0.12 million, Jharkhand with 0.96 million people) as compared to Maharashtra and Tamil Nadu (9.2 and 4.8 million, respectively) (Anjana et al., 2011). The suggested reason for this 
difference could be due to the north Indians being migrant Asians and south Indians being the host populations (Arora et al., 2010).

Factors responsible for diabetes mellitus may be the sedentary lifestyle, decrease in physical activity, increase in calorie and fat intake, history of gestational diabetes and stress. The shift in the age of onset of the diabetes is also observed, it has shifted to younger age population. As young Individuals with diabetes face the complications of diabetes, the economic productivity of this section of society may decline and this will affect the national economic productivity significantly (Yesudian et al., 2014 and Sharma et al., 2016). It could have long-lasting adverse effects on a nation's health.

Though there is an increased prevalence of diabetes within the country but there is no nationwide and very few multi-centric studies being conducted on assessing the prevalence of diabetes mellitus and its complications. The studies which have been conducted may also be prone to some potential error because of the heterogeneity of the Indian population with respect to ethnicity, culture, socioeconomic settings, mean that the expectation of regional results may not give accurate estimates for the entire country. There are many determinants that affect the prevalence of diabetes in the country and to identify those factors is necessary to make the possible change, to bring down mortality and financial burden over a developing country like India. The present study was planned with the objective to examine the relationship of diabetes mellitus with various anthropometric parameters of diabetic and non diabetic men.

\section{Materials and Methods}

\section{Location of the study}

The study was carried out in 12 blocks of Ludhiana district (Punjab).

\section{Selection of the subjects}

The sampling design used for the study was 30 cluster multi-stage sampling. A total of 30 locations from Ludhiana district were selected targeting adult men. In the next stage of sampling 12 blocks of Ludhiana district were selected. From each block two villages (total of 24 villages) and 6 locations from the urban area were selected in order to have a total random sample size of 387 subjects in the age group $\geq 20$ years, representing the rural and urban areas of Ludhiana.

\section{Anthropometric measurements}

Basic anthropometric parameters such as Weight, height, hip circumference and waist circumference were taken using standard methods (Jelliffe, 1966) and Body Mass Index (BMI) and Waist to Hip ratio (WHR) as derived indicators of abdominal obesity were calculated.

\section{Derived anthropometric measurements Body Mass Index (BMI)}

Body mass index of the subjects was estimated using formula given by WHO expert consultation (2004).

Body mass index $\left(\mathrm{kg} / \mathrm{m}^{2}\right)=$ Weight in kilograms / (Height in meters) ${ }^{2}$

\begin{tabular}{|c|c|}
\hline $\begin{array}{c}\text { Range of BMI of } \\
\text { Asians }\left(\mathrm{kg} / \mathrm{m}^{2}\right) \\
\end{array}$ & Nutritional status \\
\hline$<18.5$ & Underweight \\
\hline $18.5-22.99$ & Normal \\
\hline $23-24.99$ & Overweight \\
\hline $25-29.9$ & Pre-Obese \\
\hline 30 & Obese \\
\hline $30-40$ & Obese grade I \\
\hline $40.1-50$ & Obese grade II \\
\hline$>50$ & Obese grade III \\
\hline
\end{tabular}




\section{Waist to Hip Ratio (WHR)}

Following formula was used to calculate waist and hip ratio:

Waist and hip ratio $=\frac{\begin{array}{c}\text { Waist circumference } \\ (\mathrm{cm})\end{array}}{\begin{array}{c}\text { Hip circumference } \\ (\mathrm{cm})\end{array}}$

A reference value of $\geq 0.90$ for waist and hip ratio was taken for men (WHO 2008).

\section{Anthropometric measurements}

The anthropometric measurements of diabetic and non diabetic men are given in Table 1 (Fig. 1).

\section{Height}

The average height of the rural diabetic and non diabetic men ranged from 155-189 cm and $151-190 \mathrm{~cm}$, respectively. The average height of the rural diabetic and non diabetic men was found $172.08 \mathrm{~cm}$ and $171.55 \mathrm{~cm}$, respectively. The average height of the urban diabetic and non diabetic men ranged from $153-189 \mathrm{~cm}$ and $152-188 \mathrm{~cm}$, respectively. The average height of the urban diabetic and non diabetic men was found $170.05 \mathrm{~cm}$ and $171.98 \mathrm{~cm}$, respectively. Neetu (2014) has reported $170.20 \mathrm{~cm}$ average height of men suffering from metabolic syndrome whereas Madhu (2014) has given $167.2 \mathrm{~cm}$ average height of diabetic men.

\section{Weight}

The average body weight of rural diabetic and non diabetic men ranged from $39.8-120 \mathrm{~kg}$ and $37-120 \mathrm{~kg}$, respectively. The mean body weight of rural diabetic men was $(78.85 \mathrm{~kg})$ significantly $(\mathrm{p} \leq 0.01)$ higher as compared to non diabetic subjects $(72.14 \mathrm{~kg})$. The body weight of urban diabetic and non diabetic men ranged from $54-105 \mathrm{~kg}$ and $42-100 \mathrm{~kg}$, respectively. The average body weight of urban diabetic men was also significantly higher $(75.58 \mathrm{~kg})(\mathrm{p} \leq 0.01)$ as compared to urban non diabetic subjects $(70.97 \mathrm{~kg})$. Madhu (2014) has reported $77.56 \mathrm{~kg}$ average weight of diabetic males and Neetu (2014) has reported average weight of men to be $76.50 \mathrm{~kg}$.

\section{Waist circumference}

The average waist circumference of rural diabetic and non diabetic men ranged from ranged from $71-130 \mathrm{~cm}$ and $69-132 \mathrm{~cm}$, respectively. The average waist circumference of rural diabetic men was $(102.25 \mathrm{~cm})$ significantly $(\mathrm{p} \leq 0.01)$ higher when compared to rural non diabetic men $(96.83 \mathrm{~cm})$. The waist circumference of urban diabetic and non diabetic men ranged from 50.8-127 cm and $71.12-124.46 \mathrm{~cm}$, respectively. The average waist circumference of urban diabetic men was $(101 \mathrm{~cm})$ significantly $(\mathrm{p} \leq 0.01)$ higher when compared to urban non diabetic men (98.88 cm). Neetu (2014) has reported the average waist circumference of diabetic men to be 99.94 .

\section{Hip circumference}

The average hip circumference of rural diabetic and non diabetic men ranged from $73.66-127 \mathrm{~cm}$ and $63.5-124 \mathrm{~cm}$, respectively. The average hip circumference of rural diabetic men was $(101.56 \mathrm{~cm})$ significantly higher $(\mathrm{p} \leq 0.01)$ as compared to rural non diabetic men $(96.34 \mathrm{~cm})$. The hip circumference of urban diabetic and non diabetic men ranged from 67.31-121.92 cm and 71.14-125.51 cm, respectively. The average hip circumference of urban diabetic men was $(100.43 \mathrm{~cm})$ significantly higher $(\mathrm{p} \leq$ $0.01)$ as compared to urban non diabetic men $(97.09 \mathrm{~cm})$. Hip circumference of diabetic men was reported $103.13 \mathrm{~cm}$ by Neetu (2014). 
Derived anthropometric measurements of diabetic and non diabetic men

\section{Body mass index}

The average BMI of rural diabetic and non diabetic men ranged from $14.20-43.70 \mathrm{~kg} / \mathrm{m}^{2}$ and $13-46.60 \mathrm{~kg} / \mathrm{m}^{2}$, respectively. The average BMI of rural diabetic men was significantly $(\mathrm{p} \leq 0.01)$ higher $\left(26.82 \mathrm{~kg} / \mathrm{m}^{2}\right)$ as compared to rural non diabetic men $(24.64$ $\mathrm{kg} / \mathrm{m}^{2}$ ). The BMI of urban diabetic and non diabetic men ranged from $18.9-43.3 \mathrm{~kg} / \mathrm{m}^{2}$ and $13-41.2 \mathrm{~kg} / \mathrm{m}^{2}$, respectively. The average BMI of urban diabetic men was significantly $(p \leq 0.01)$ higher $\left(26.71 \mathrm{~kg} / \mathrm{m}^{2}\right)$ as compared to rural non diabetic men $\left(24.91 \mathrm{~kg} / \mathrm{m}^{2}\right)$. The average BMI $27.59 \mathrm{~kg} / \mathrm{m}^{2}$ has been reported by Madhu (2014).

\section{Waist to hip ratio}

The Waist hip ratio of rural diabetic and non diabetic men ranged from 0.9-1.1 and 0.81 and 1.71, respectively. The average waist to hip ratio of rural diabetic and non diabetic men was 1.01. The WHR of urban diabetic and non diabetic men ranged from 0.8-1.1 and $0.91-1.18$, respectively. The average waist to hip ratio of urban diabetic and non diabetic men was 1.01 and 1.02, respectively.

\section{Body Mass Index (BMI) of rural and urban men}

Body mass index of men is given in Table 2 (Fig. 2). Higher body mass index has been significantly associated with the diabetes risk. The role of body mass index with the development of diabetes has been well established which is again reinforced by the present study. It was seen that significantly higher number of rural non diabetic men (12\%) were underweight as compared to rural diabetic men (4\%). It was found that 29 per cent rural diabetic men and 27 per cent non diabetic men were in the normal weight category. 10 per cent rural diabetic men and 18 per cent rural non diabetic men were overweight. It was observed that significantly higher number $(26 \%)$ of rural diabetic men were in obesity grade I category as compared to rural non diabetic subjects (9\%) while 4 per cent rural diabetic and 2 per cent non diabetic men were in obesity grade II category. Among urban men, 5 per cent non diabetic men were under weight. It was found that 28 per cent urban diabetic men and 27 per cent non diabetic men were in the normal weight category while 19 per cent urban diabetic and 18 per cent non diabetic men were overweight. It was observed that significantly higher number $(22 \%)$ of urban diabetic men were in obesity grade I category as compared to urban non diabetic subjects $(7 \%)$, while 2 per cent urban diabetic and 2 per cent non diabetic men were in obesity grade II category.

Studies have shown that obesity has role in the development of diabetes. The obesity progresses to diabetes by progressive defect in insulin secretion along with simultaneous rise in insulin resistance (Shobha and Deepali, 2016). The mechanism which links obesity with diabetes is the adipose tissue especially the visceral fat which is deposited in the abdomen can alter the metabolism by increasing the release of proinflammatory markers, fatty acids, glycerol which decrease the sensitivity of insulin. This insulin insensitivity with failure of pancreas to release insulin constitutes the development of Type 2 diabetes (Kahn et al., 2006). It has been evident that the Asian Indians are more susceptible to risk factors like age, adiposity (based on BMI) and central obesity (WHR). The risk of diabetes mellitus was observed to be significant for urban population with BMI more than $23 \mathrm{~kg} / \mathrm{m}^{2}$ (Chandalia et al., 1999). 
Table.1 Anthropometric measurements of men

\begin{tabular}{|c|c|c|c|c|c|c|c|}
\hline \multirow{2}{*}{\multicolumn{2}{|c|}{$\begin{array}{l}\text { Basic Anthropometric } \\
\text { measurements }\end{array}$}} & \multicolumn{2}{|c|}{ Rural } & \multirow{3}{*}{$\begin{array}{c}\text { t-value } \\
0.31^{\mathrm{NS}}\end{array}$} & \multicolumn{2}{|c|}{ Urban } & \multirow{3}{*}{$\begin{array}{r}\text { t-value } \\
0.35^{\mathrm{NS}}\end{array}$} \\
\hline & & \multirow{2}{*}{$\begin{array}{c}\begin{array}{c}\text { Diabetic } \\
(\mathbf{n}=\mathbf{1 0 1})\end{array} \\
155-189 \\
172.08 \pm 0.88\end{array}$} & \multirow{2}{*}{$\begin{array}{c}\text { Non diabetic } \\
(\mathbf{n}=\mathbf{1 7 2})\end{array}$} & & \multirow{2}{*}{$\begin{array}{c}\begin{array}{c}\text { Diabetic } \\
(\mathbf{n}=\mathbf{5 8})\end{array} \\
153-189 \\
170.05 \pm 1.10\end{array}$} & \multirow{2}{*}{$\begin{array}{c}\begin{array}{c}\text { Non diabetic } \\
(\mathbf{n}=\mathbf{5 6})\end{array} \\
152-188 \\
171.98 \pm 1.22\end{array}$} & \\
\hline Height, cm & $\begin{array}{c}\text { Range } \\
\text { Mean } \pm \text { SE }\end{array}$ & & & & & & \\
\hline Weight, kg & $\begin{array}{c}\text { Range } \\
\text { Mean } \pm \text { SE }\end{array}$ & $\begin{array}{c}39.8-120 \\
78.85 \pm 1.63\end{array}$ & $\begin{array}{c}37-120 \\
72.14 \pm 1.10\end{array}$ & $44.70^{* * *}$ & $\begin{array}{c}54-105 \\
75.58 \pm 1.71\end{array}$ & $\begin{array}{c}42-100 \\
70.97 \pm 1.74\end{array}$ & $18.73^{* * *}$ \\
\hline $\begin{array}{l}\text { Waist circumference, } \\
\text { cm }\end{array}$ & $\begin{array}{c}\text { Range } \\
\text { Mean } \pm \text { SE }\end{array}$ & $\begin{array}{c}71-130 \\
102.25 \pm 1.22\end{array}$ & $\begin{array}{c}69-132 \\
96.83 \pm 1.27\end{array}$ & $38.85^{* * *}$ & $\begin{array}{c}50.8-127 \\
101.84 \pm 1.95\end{array}$ & $\begin{array}{c}71.12-124.46 \\
98.88 \pm 1.71\end{array}$ & $11.69^{* * *}$ \\
\hline $\begin{array}{l}\text { Hip circumference, } \\
\text { cm }\end{array}$ & $\begin{array}{c}\text { Range } \\
\text { Mean } \pm \text { SE }\end{array}$ & $\begin{array}{c}73.66-127 \\
101.56 \pm 1.08\end{array}$ & $\begin{array}{c}63.5-124 \\
96.34 \pm 0.83\end{array}$ & $41.90^{* * *}$ & $\begin{array}{c}67.31-121.92 \\
100.43 \pm 1.58\end{array}$ & $\begin{array}{c}71.14-125.51 \\
97.09 \pm 1.56\end{array}$ & $14.23^{* * *}$ \\
\hline \multicolumn{8}{|c|}{ Derived Anthropometric measurements } \\
\hline $\begin{array}{l}\text { Body Mass Index, } \\
\text { kg/m² }\end{array}$ & $\begin{array}{c}\text { Range } \\
\text { Mean } \pm \text { SE }\end{array}$ & $\begin{array}{c}14.2-43.7 \\
26.82 \pm 0.63\end{array}$ & $\begin{array}{c}13-46.6 \\
24.64 \pm 0.41\end{array}$ & $23.48^{* * *}$ & $\begin{array}{c}18.9-43.3 \\
26.71 \pm 0.76\end{array}$ & $\begin{array}{c}13-41.2 \\
24.91 \pm 0.62\end{array}$ & $11.58^{* * *}$ \\
\hline Waist/Hip ratio & $\begin{array}{c}\text { Range } \\
\text { Mean } \pm \text { SE }\end{array}$ & $\begin{array}{c}0.9-1.1 \\
1.01 \pm 0.01\end{array}$ & $\begin{array}{l}0.81-1.71 \\
1.01 \pm 0.01\end{array}$ & NA & $\begin{array}{c}0.8-1.1 \\
1.01 \pm 0.01\end{array}$ & $\begin{array}{l}0.91-1.18 \\
1.02 \pm 0.01\end{array}$ & $0.53^{\mathrm{NS}}$ \\
\hline
\end{tabular}

Values represent Mean \pm SE

*Significant at 10\%; **Significant at 5\%; *** Significant at 1\%; NS-Non Significant 
Int.J.Curr.Microbiol.App.Sci (2020) 9(10): 2391-2400

Table.2 Body mass index of diabetic and non diabetic men

\begin{tabular}{|c|c|c|c|c|c|c|c|}
\hline \multirow[b]{2}{*}{ BMI $\left(\mathrm{kg} / \mathrm{m}^{2}\right)$} & \multirow[b]{2}{*}{ Category } & \multicolumn{2}{|c|}{ Rural } & \multirow[b]{2}{*}{$\mathbf{Z}$ value } & \multicolumn{2}{|c|}{ Urban } & \multirow[b]{2}{*}{$Z$ value } \\
\hline & & $\begin{array}{l}\text { Diabetic } \\
(n=101)\end{array}$ & $\begin{array}{l}\text { Non diabetic } \\
\qquad(n=172)\end{array}$ & & $\begin{array}{c}\text { Diabetic } \\
(n=58)\end{array}$ & $\begin{array}{l}\text { Non diabetic } \\
\qquad(n=56)\end{array}$ & \\
\hline$<18.5$ & Underweight & $4(4)$ & $20(12)$ & $2.16^{* *}$ & - & $3(5)$ & $1.79^{*}$ \\
\hline 18.5-22.99 & Normal & $29(29)$ & $46(27)$ & $0.35^{\mathrm{NS}}$ & $16(28)$ & $15(27)$ & $1.71^{*}$ \\
\hline 23-24.99 & Overweight & $10(10)$ & $31(18)$ & $1.81^{*}$ & 11(19) & $10(18)$ & $1.42^{\mathrm{NS}}$ \\
\hline 25-29.9 & Pre-Obese & $28(28)$ & $56(33)$ & $0.84^{\mathrm{NS}}$ & $17(29)$ & $23(41)$ & $0.28^{\mathrm{NS}}$ \\
\hline 30 & Obese & - & - & - & - & - & - \\
\hline $30-40$ & Grade I & $26(26)$ & 16(9) & $3.63^{* * *}$ & $13(22)$ & $4(7)$ & $3.92^{* * *}$ \\
\hline 40.1-50 & Grade II & $4(4)$ & $3(2)$ & $1.12^{\mathrm{NS}}$ & $1(2)$ & $1(2)$ & $0.32^{\mathrm{NS}}$ \\
\hline$>50$ & Grade III & - & - & - & - & - & \\
\hline
\end{tabular}

Figures in parenthesis represent percentages.

*Significant at $10 \%$ level; **Significant at $5 \%$ level; *** Significant at $1 \%$ level; NS-Non Significant 


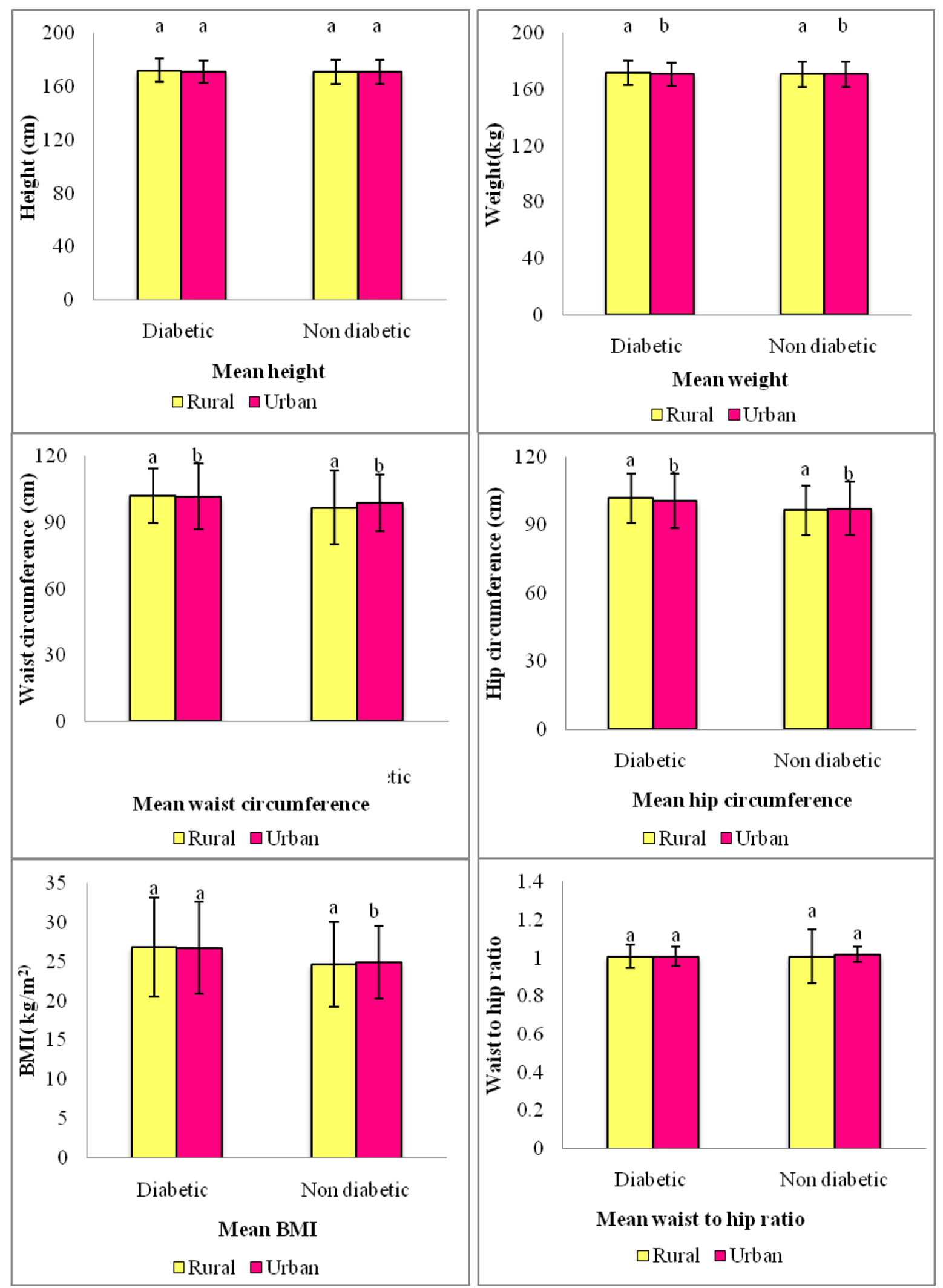

Fig.1 Anthropometric measurements of diabetic and non diabetic men 


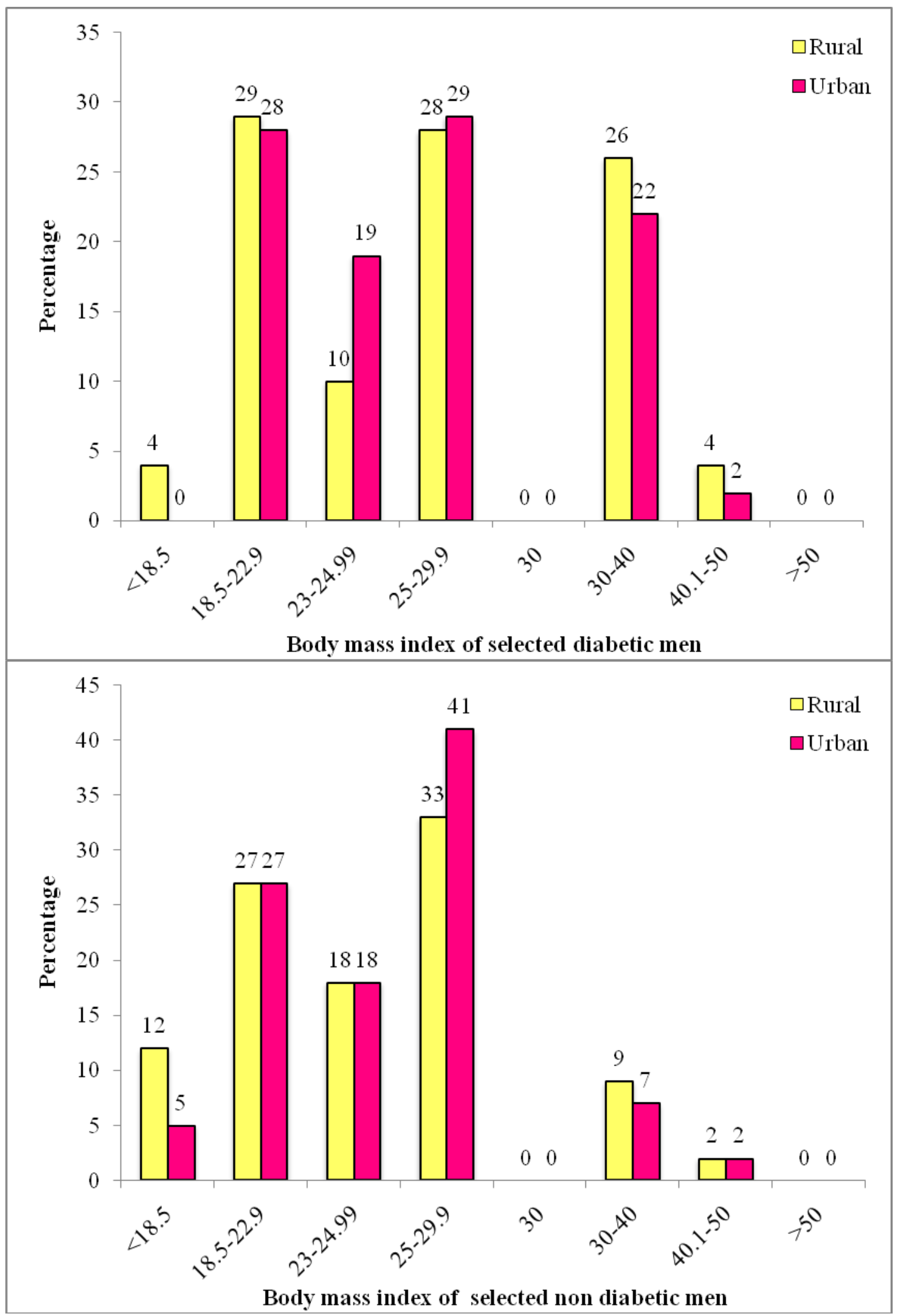

Fig.2 Body mass index (BMI) of rural and urban men 
Present study showed that diabetes mellitus prevalence was high among pre obese (28\% rural and 29\% urban) and obese grade I subjects (26\% rural and $22 \%$ urban). It was also evident that risk of age adjusted diabetes mellitus starts to increase with the BMI in both males and females. Also in both areas, present study showed that there was an increasing trend of diabetes mellitus prevalence among men and women.

Resnick et al., (2000) observed that each $\mathrm{kg}$ of weight lost annually over 10 years was associated with a 33 per cent lower risk of diabetes in the subsequent 10 years. Snehalatha et al., (2003) reported that generally people get diabetes if their BMI was between $30-31 \mathrm{~kg} / \mathrm{m}^{2}$. Indians can develop diabetes if their BMI is above $25 \mathrm{~kg} / \mathrm{m}^{2}$. The normal cut off value for BMI in Asian Indian adults is $<23 \mathrm{~kg} / \mathrm{m}^{2}$ and waist hip ratio is 0.80-0.88. Similarly, Klein et al., (2004) stated that the marked increase in the prevalence of overweight and obesity was responsible for the recent increase in the prevalence of NIDDM.

In conclusion, it was found that the mean body weight, mean waist circumference, mean hip circumference and mean body mass index (BMI) of rural and urban diabetic men was significantly higher $(\mathrm{p} \leq 0.01)$ as compared to rural and urban non diabetic men. It indicates that anthropometric parameters are a modifiable risk factors of type 2 diabetes. It is indicated that people should be encouraged to be physically active to maintain their body weight, waist/hip circumference and BMI in normal/ reference range to prevent and manage diabetes.

\section{References}

Anjana R M, Pradeepa R, Deepa M, Datta M, Sudha V, Unnikrishnan R, Bhansali A, Joshi S R, Joshi P P, Yajnik C S,
Dhandhania V K, Nath L M, Das A K, Rao P V, Madhu S V, Shukla D K, Kaur T, Priya M, Nirmal E, Parvathi S J, Subhashini S, Subashini R, Ali M K and Mohan V (2011) Prevalence of diabetes and prediabetes (impaired fasting glucose and/or impaired glucose tolerance) in urban and rural India: phase I results of the Indian Council of Medical Research-INdiaDIABetes (ICMR-INDIAB) study. Diabetologia 54: 3022-27.

Arora V, Malik J S, Khanna P, Goyal N, Kumar N and Singh M (2010) Prevalence of diabetes in urban Haryana. Australas Med J 3(8): 488-94.

Chandalia M, Abate N, Garg A, StrayGundersen J and Grundy SM (1999) Relationship between generalized and upper body obesity to insulin resistance in Asian Indian men. J Clin Endocrinol Metab 84(7): 2329-35.

Jellife D B (1966) The Assessment of Nutrition Status of the Community. World Health Organisation Monograph series No.53, Geneva: 50-84.

Joshi S R and Parikh R M (2007) India diabetes capital of the world: now heading towards hypertension. $J$ Assoc Physicians India 55: 323-24.

Kahn S E, Hull R L and Utzschneider K M (2006) Mechanisms linking obesity to insulin resistance and Type 2 Diabetes Mellitus. Nature 444: 840-46.

Klein S, Sheard NF, Pi-Sunyer X, Daly A, Wylie-Rosett J, Kulkarni K and Clark N G (2004) Weight management through lifestyle modification for the prevention and management of type 2 diabetes: rationale and strategies. Am J Clin Nutr 80(2): 257- 63.

Kumar A (2013) Prevalence of Glycemic Status, Obesity \& Waist Circumference in Punjabi Type 2 Diabetics. Journal of Exercise Science and Physiotherapy 9(1): $1-5$. 
Madhu (2014) Impact of supplementation of broccoli products (Brassica Oleracea L Var Italica plenck) on blood glucose and lipid profile of non insulin dependent diabetics. Ph.D. Dissertation, Punjab Agricultural University, Ludhiana, India.

Neetu (2014) Development of novel functional foods for metabolic syndrome. Ph.D. Dissertation, Punjab Agricultural University, Ludhiana, India.

Resnick H, Valsania P, Halter J and Lin X (2000) Relation of weight gain and weight loss on subsequent diabetes risk in overweight adults. $J$ Epidemiol Community Health 54: 596-602.

Sharma K M, Ranjani H, Zabetian A, Datta M, Deepa M, Moses C R A, Narayan K M V, Mohan V and Ali M K (2016) Excess cost burden of diabetes in Southern India: a clinic-based, comparative cost-of-illness study. Glob Health Epidemiol Genom.13; 1: e8. doi: 10.1017/gheg.2016.2. eCollection 2016.

Shobha M V and Deepali A (2016) Indian Diabetic Risk Score (IDRS): A novel tool to assess the risk of Type 2
Diabetes Mellitus. Indian J Basic and Applied Med Res 5(4): 106-10.

Snehalatha C, Ramachandran A, Satyavani K, Sivasankari S and Vijay V (2003) Clustering of cardiovascular risk factors in impaired fasting glucose and impaired glucose tolerance. Int J Diab Dev Ctries 23: 59-61.

WHO (2004) Appropriate body mass index for Asian populations and its implications for policy and intervention strategies: World Health Organization expert consultation. Lancet 363: 157-63.

WHO (2008) Waist Circumference and Waist-Hip Ratio: Report of a WHO Expert Consultation World Health Organization, Geneva.

Wild S, Roglic G, Green A, Sicree R and King H (2004) Global prevalence of diabetes-estimates for the year 2000 and projections for 2030. Diabetes Care 27(3): 1047-53.

Yesudian C A, Grepstad M, Visintin E and Ferrario A (2014) The economic burden of diabetes in India: a review of the literature. Global Health 10: 80.

\section{How to cite this article:}

Karmjeet Kaur, Harpreet Kaur, Kiran Bains and Jaswinder K. Brar. 2020. A Study of Anthropometric Profile of Diabetic and Non Diabetic Men. Int.J.Curr.Microbiol.App.Sci. 9(10): 2391-2400. doi: https://doi.org/10.20546/ijcmas.2020.910.286 